\title{
DEVELOPMENT OF WINE SECTOR - A WAY TO SUSTAIN WINE TOURISM IN ROMANIA
}

\author{
Andra-Elena Gurgu \\ Bucharest University of Economic Studies, Romania, gurguandra@gmail.com
}

\begin{abstract}
This article aims to identify the influence of wine sector toward wine tourism in Romania. The article describes both wine sector and wine tourism. The study attempts to demonstrate the correlation between these two sectors pointing out that wine tourism in Romania is still in a developing phase. Therefore, understanding the link between these two merging industries and how they influence each other stands as the goal of the paper. Overall, the results suggest that there is a significant wine-growing potential with a conclusive outcome in wine tourism sector.
\end{abstract}

Keywords:

Wine tourism, wine sector, development, vineyard

JEL Classification: L83, L66, Z32

DOI: $10.24818 / \mathrm{CTS} / 3 / 2021 / 1.05$

\section{Introduction}

Wine tourism in Romania seems to appeal to an increasing number of people, not only to wine professionals but also for wine enthusiasts or simple wine consumers. People are interested to expand their knowledge about different types of wine, wine industry, varieties or wine cellars stories. The desire for knowledge brings benefits for a new thematic type of tourism while the implementation of new economic activities result in additional income for the producers and communities involved.

Wine tourism is recognized as a part of agricultural tourism, rural tourism and gastronomic tourism. While wine consumption is increasing, wine growing is becoming an important tool of regional development. However, on global level wine production is growing faster than the consumption transforming wine sector into a competitive business environment (Hall and Mitchell, 2008).

In Romania, growing grapes represents a way to value less fertile land and also an important tool to protect the environment. In the last years, the niche of wine tourism gave the chance to some rural areas to flourish due to the changes in customer behavior which became more interested to discover cultural experiences, traditions and natural environment (Chirita, 2018).

The importance of wine sector development influences interest for wine tourism. For instance, producer's investment in new technologies for vinification process in order to obtain qualitative wines. On the other hand, manufacturers invest in technologies that have the role to protect and feed the vineyards to get better grapes to produce wine. In this way, producers are ensuring a high-quality wine, good production, and as a result an increase in sales. One more important aspect is advertising, producers have to promote their products and services to attract consumers to visit their wine cellars (Hall, 2000).

The high potential of wine tourism in Romania should encourage producers and wine cellar owners to create attractive wine tourism packages. The existence of wine tourism framework is a great opportunity for wine producers to expand their business taking into consideration that due to the COVID-19 pandemic both tourism and wine sector have been seriously affected. Therefore, for the future emerging these two industries might represent a potential solution to recover from the pandemic effects.

\section{Literature review}

Wine tourism is a niche tourism product that is increasing across the world. Wine tourism is also seen as a sustainable approach to tourism due to its positive impact to economic, cultural and social activities (Sorensen, 2013). The competitiveness between wine regions has become a strategic issue, as the 
volume of wine tourism has been increasing, producers around the world are marketing their businesses in order to attract the tourist in their area (Getz and Brown, 2004).

\subsection{Wine tourism}

According to World Tourism Organization (2016) in the last decade wine tourism has become a key component of gastronomic tourism. Furthermore, wine tourism is used as a strategy for many destinations in order to attract customers and to improve the touristic offer. In 2017 Afonso et al. stated that wine tourism is a niche tourism product that is growing in wine regions from the entire world. Also, in the past years wine tourism events increased due to high interested in wines from customer's side.

Worldwide, wine production and tourism are connected for a long time and both Old World (France, Italy, Spain, Portugal, Germany) and New World (USA, Chile, South Africa, Australia, New Zeeland) are taking advantage of the dynamism of this type of tourism. The producers are trying to create great experiences for consumers offering various services at the wine cellar, for example: accommodation, food and wine pairing, local traditions, vinification process presentations, vineyard horse walks or grapes harvest etc. (Nedelcu, 2014).

The concept of wine tourism was described by many authors, according to Hall (1996) wine tourism can be defined as a visit to a specific wine region where people can explore the vineyards, wineries and wine cellars for wine tasting motivations, while Getz (2004) stated three perspectives of wine tourism. The first perspective reffers to wine tourism as being a strategy for increasing the number of visitors in a specific region. Regarding the second perspective, this sustains that wine tourism is linked to customer's behaviour related to wine while the third perspective sees wine tourism as an opportunity for wine producers to educate their customers.

\subsubsection{Wine experiences}

In the past year's companies were focused to create experiences for their customers. In the process of purchasing touristic packages, besides accommodation and food services, people are also looking to the main activities and how they can spend their time in the area.

Tourism experiences are now mandatory, as Thanh and Kirova in 2017 present an innovative approach regarding wine experiences. The authors detail the 4E's: educational, esthetic, entertainment and escapism experience. The study of Thanh and Kirova was based on an analysis of Cognac, France which is a known wine area, where the reviews from Tripadvaisor were examined and the attributes of each experience was describes.

The first experience is educational that consist in education of the customers which is the main motivation for visits. People come to the wine cellar to learn and expand knowledge about wines, like varieties, types, wine and food pairing.

Esthetic experience refers to harmony of the environment. The main motivation is winescape which can consist in cultural and environmental activities, for example a typical activity is driving while admiring the vineyards on country roads between vines. Also, it can be included the architecture, design or decoration of the wine cellar or the tasting room.

The entertainment experience consists of dynamic events, like festivals, open day in wine destination areas. On the other hand, the events could be related to music, art, cultural heritage or food within a wine region in order to ensure diversity for consumers.

Finally, the escapist dimension is based on unusual activities. Thus, customers want to escape from daily routine and they are going to wine cellars to try new activities. The important factor to consider is that tourists prefer to do different activities rather than only visit. Some examples of escapist activities are: vineyard hiking, bicycle tours, hot air ballooning activity above vineyards, grape harvesting or any other activities that could be related to wine.

\subsubsection{Wine tourist}

Wine tourist is someone who participate to activities related to wine, such as visit of vineyards and wineries, tastings, wine events etc. as per Hall (1996). The motivations of a wine tourist may differ 
depending on their interests, education, income as below paragraph presents the segmentation of wine tourists (Hall, 1996):

- Wine lovers - they have a high interest in wine. Usually, these people are working in wine sector and they have high education and income. Also, wine lovers are regular wine buyers, as well as wine and gastronomic magazines.

- Wine interested - besides interest in wine, these people practice wine tourism for landscapes and for the activities related to wine. Wine interested people have medium income, knowledge about wine production, they read about wine but do not travel frequently in wine destinations.

- The curious tourist - they visit wine destinations out of curiosity about what wine tourism consist of, not because they are wine oriented. These are people with moderate income and education without knowledge about winemaking process.

Charters and Ali-Knight (2002) classify wine tourists as following:

- Wine lovers - they have strong knowledge about wine, they regularly visit wine cellars and buy wine from the source.

- Wine Connoisseurs - it is a subcategory of wine lover; they have deep knowledge in wines.

- Wine interested - they have some knowledge in wine tasting, their motivation to visit a wine cellar is to learn about wines.

- Wine novices - they find attractive to visit a wine cellar out of curiosity, the main motivation to visit is to taste wine. Also, wine novices do not have knowledge in wines, but they participate to activities related to wine when they have the opportunity.

- The Hanger-on - they visit a wine cellar as a part of a group, they do not have interest in wine at the time of the visit.

\subsubsection{Wine tourism in Romania}

Romanian wine tourism was in an incipient phase until few years ago. Nowadays, more and more wineries have created wine tourism offers. At the vineyard people can see the places where wine is produced and stored, participate to tastings and pairings sessions, enjoy peace and relaxation in nature. The wineries start to understand wine tourism as a way to promote wines and increase sales, the investments becoming more and more elaborate and thought out in the long run. In Romania, wine tourism development is going slowly, not as other consumption segments but the growth is constant, healthy and reflects the high number of potential tourists (Tanase, 2017).

Wine tourism in Romania is provided by the wine heritage and the viticulture development from the past few years. The climate and soil are favourable for vineyards which are directly influencing wine quality. Since 1990 Romanian viticulture and wine industry suffered a radical transformation: the hybrid grapes varieties were replaced with noble varieties in order to produce high-quality wine and new vineyards were cultivated (Nedelcu, 2014).

The most developed viticulture is found in the centre of Romania, especially Prahova - Buzau County. There are many vineyards and wineries such as Lacerta, Ceptura, Tohani, Serve, Budureasca etc. Also, on Romanian wine map it can be mentioned Dobrogea County with Alira, Sarica Niculitel, Rasova etc., Moldova area with Cotnari, Panciu or Girboiu Wine cellars; Transylvania - Jidvei and Banat - Recas (Wine map of Romania, www.crameromania.ro).

Moreover, there are statistics that place Romania in a rather favourable position in terms of its participation as wine destination. Thus, Romania is the 13th world wine producer country by volume and the 5th European producer in terms of cultivated area. Furthermore, less than 60 of the approximately 150 wineries that produce bottled wine practice wine tourism. This includes tastings, presentations related to wine and production process, private events, touristic packages in the vicinity of the winery, and so on. Hence, a closer collaboration between the wine producers could take wine tourism to another level (Bolcu, 2021). 


\subsubsection{Romanian wine tourism projects}

Urlateanu Mansion (Azuga, Prahova County) is an aristocratic house built in 1922, purchased by Halewood in 2000. Here guests learn about the process of maturing wine in barrels and how to store bottled wines in the wine cellar. At the end of the visit and tasting, lunch or dinner can be served at the winery restaurant. Founded in Azuga in 1892, Rhein \& CIE Cellars is the oldest location in Romania where sparkling wine is produced using the traditional method. Halewood arranged here a three-star pension where it transformed the winery spaces into 16 guest rooms, a restaurant with two salons, a small museum and a wine shop. Also, among the leisure facilities offered to tourists are badminton and volleyball court, table tennis, gazebo with two barbecue areas (Tanase, 2017).

Located in Vrancea County, Domeniile Panciu is in the last stage of the project, completed in proportion of $75 \%$. The touristic complex has a four-star hotel with 27 rooms, a tasting room, a restaurant, conference space, summer terrace with retractable roof and glass side walls, swimming pool with terrace and pool bar, spa (sauna, fitness equipment, massage room), bike path through the vineyard with a length of almost $10 \mathrm{~km}$, tennis court, children's playgrounds, entertainment area (billiards, table tennis). Those who will visit Panciu Domains will also be able to do tours with tasting at the winery, also to visit the Ana Are juice factory, blueberry plantations and many others activities. The tourist packages offered will be in two variants: all-inclusive and a la carte (Tanase, 2017).

Liliac Winery has in the middle of the vineyards of Batos in Mures County a lodge made in minimalist style where it organizes tastings and private events. Thus, the manufacturer intends to build 10-12 independent accommodation units of two to four places each. Interested tourists will be able to spend two to three days isolated from the urban noise, in the middle of the vineyard. The facilities offered will be traditional, with breakfast on the terrace of the chalets, common dinner by campfire, music and socializing (Tanase, 2017).

GRAMMA Winery from Iasi plans to open eight premium tiny homes. They will each have a usable area of 24 square meters and will be placed in a newly planted vineyard. The cottages can accommodate two people and each will have a swimming pool, sleeping space or living room with generous glazed spaces. The cottages are isolated from each other, which offers privacy, comfort and minimal interaction between tourists. The winery owners also plan to renovate their wine tasting and presentation room (Dobreanu,2021).

Romanian wine industry is now more valuable due to the interest of many parties. The support that comes from government, stakeholders, private companies and investors is encouraging the wine producers to collaborate to develop touristic packages for their customers. In order to expand the wine tourism, the producers are looking to invest in accommodation, restaurants and other entertainment activities beside the ones related to wine.

Overall, wine tourism has a tremendous potential to become a key factor on Romania tourism map. The development of wine tourism has a direct influence not only in wine sector development, but also to local economy. For this reason, wine tourism is adding value to socio-economic segments of the regions where this type of tourism is practice.

\subsection{Romania's wine sector}

During Viticon 2021 Conference sponsored by Agricover were presented many innovations and tools to sustain wine sector. Romania has 180,000 hectares with vineyards, and it ranks 5th in Europe in terms of cultivated area. Taking into consideration the production, Romania ranks 6th with 3,55 million hectolitres.

Considering the above, the Ministry of Agriculture and Rural Development propose Programul Național de Sprijin in sectorul vitivinicol 2019-2023 (National Support Program in the wine sector 2019-2023). The program consists in the following actions presented by the Minister of Agriculture and Rural Development, Adrian Nechita Oros during Viticon Conference 2021.

The first measure is that EU Member States are responsible of wine consumption and to control designation of origin and geographical indications of wines. The actions that can be carried out through information campaigns and participation to important events, fairs and exhibitions at national or EU 
level. Beneficiaries of financial support for this measure are producers in the wine sector. A second measure lies in promotion in third countries in order to improve the competitiveness of wine sector and also to create new opportunities for exports.

In scope of restructuring/reconversion of vineyards a measure was introduced for wine producers to restructure or modernize their areas with vines in order to increase competitiveness and to adapt to current market requirements. Restructuring/conversion programs for vineyards include the following eligible actions:

- the conversion of varieties;

- relocation of wine plots;

- replanting due to compulsory deforestation of vineyards for sanitary reasons;

- the installation of drip irrigation systems.

Harvest insurance is a measure for producers in the wine sector to benefit from increased income stability by ensuring areas against climatic phenomena with adverse effects similar to natural disasters. The last measure consists in financial support granted for increasing the competitiveness of wine producers, the economic performance of enterprises, as well as for the improvement of winemaking technologies through which superior quality wines are obtained.

Besides the support that comes from Romanian Government, wine sector has the support of private companies that offer specialised services to the sector. For instance, some non-bank financial institutions created programmes that come into benefit of wine producers and farmers. The support for farmers in the wine sector constitute in an Early sales campaign that is keeping the prices from spring 2020 for most suppliers (the prices before COVID-19 pandemic). Other measures that were taken in favour of winemakers are the availability of goods, payment terms correlated with the time of harvest, free and authorized storage of goods and products in optimal conditions and their delivery at the necessary time. Cash Discount program was launched in 2010, this program is specialized in financing the producers for covering the need for inputs, purchasing of fertilizers with payment at harvest, diesel acquisition with payment at harvest, solutions for cost efficiency per hectare, unsecured loans with no interest where the loan to non-bank financial institution is paid when the culture reaches maturity.

Also, there are companies that offer complete solutions for conventional agriculture and organic agriculture, for example plant protection products, fertilizers and biostimulators for vines.

On the other hand, according to a study made by KeysFin in 2020, on the local market the wine turnover achieved approximately Lei 1.8 billion in 2019 compared to 2018 were it registered a decrease. In 2020 the turnover was up to Lei 1.7 billion. Although business decreased in 2019, the net result was almost 10 times higher than 2018, at the same time it was the best result in the last 10 years. Important to mention, it is the fact that the turnover is lower due to bad weather conditions. As per Roxana Popescu, Managing Director of KeysFin "Romania has high potential for wine production, and the fact that we have so many areas where quality wine is produced is a good indicator for the future of Romanian wine. Furthermore, the international expansion and positioning of as many brands as possible in the premium zone will contribute to market growth...".

However, Alina Iancu, founder of CrameRomania.ro and Revino.ro, briefs regarding wine cellars owner's behaviour in 2020 "The wineries have started to pay more interest in wine tourism, to be more open to tourists that come to the winery and buy wine, and considering that restaurants are mostly closed, wine sales on spot are more than welcome. But regardless of the COVID-19 pandemic situation, it is good that this segment is growing." (Stiriagricole.ro, 2020).

Nonetheless, Romania has more than 250 wine cellars, of which only approximately 200 produce bottled wine. The wineries that are also open for tourists are around 100. Of these, 25 also have accommodation units, and for the rest of the wineries that do not provide accommodation, tourists can stay in the winery area (Stiriagricole.ro, 2020). 
Thus, the support for wine sector comes from government, private companies, financial and nonfinancial institutions, other stakeholders. Wine producers are encouraged to invest and develop their businesses, to implement new technologies for wine making and to adopt wine tourism activities to attract consumers.

\section{Methodology}

In order to establish the level of support needed in Romanian wine sector, a study was conducted to provide insights into wine tourism of Romania. The research was an inductive approach that consist in two studies that provides both qualitative and quantitative data. The inductive approach lies in gathering all the data and evidence available and afterwards, general ideas to be formulated related to the subject (Quinlan, 2011).

The focus of this study was how wine industry and tourism are merging together in order to create a full-service experience for consumers. The aim of the research was to determine customers' expectations of wine tourism in Romania.

Therefore, a questionnaire with 18 questions for wine consumers and potential wine tourists was conceived. The questionnaire was firstly piloted with one sommelier and four wine interested people and as per their feedback the questions were improved. Also, the survey should be considered valid due to some facts, for instance the questions were easy to follow, and taking into account that the questionnaire was applied during wine related events there were small chances to gather data from incorrect sources. In order to obtain statistical results to identify the main perceptions and attitudes of wine consumers, as well as their motivations and expectations the survey instrument consisted of selfadministrated paper-based and online questionnaires.

In online, the questionnaire was shared in social media groups related to wine in a time frame of three weeks while the on-sight questionnaire was applied during Wine Festival in Bucharest (July 2019) to the people attending the event. At the end of the research a number of 252 responses were validated and they were analysed using SPSS software.

The qualitative data was gathered from wine producers and vineyards administrators or owners. The approach for this was the semi-structured interview that allowed to interpretation of results based on 10 open questions. Also, the framework of the subject offered to the participants made the communication easier for them to describe their perspective related to wine tourism. In total 115 wine cellars were contacted via e-mail, including all wine areas from Romania. The answers were analysed with NVivo to allow extracting key words and themes.

Both questionnaires and interviews were provided in English and Romanian due to the fact that some participants were foreign. Population sample was formed only with people above 18 years old, which was a limitation of the research because only adults can consume alcoholic beverages in Romania.

The link between qualitative and quantitative data gathered from both participating sides of wine tourism, wine producers and tourists might fill the gap in this subject. The data was put together after the collection period, it was analysed accordingly in order make comparisons among customers' expectations and what producers provide at the wine cellar.

\section{Results}

\subsection{Quantitative Analysis}

The first question of the questionnaire had the role to introduce the respondent to the theme and to decide if the person is eligible or not for the study. From a total of 252 respondents, only $10 \%$ of them said that they are not wine enthusiast while the rest of $90 \%$ answered positively. The $10 \%$ were still considered to answer the second question because as Charters and Ali-Knight (2002) said there are people that visit wine cellars with a group of wine enthusiasts or out of curiosity.

The second question of the questionnaire was formulated to decide if the respondent visited or not (in this case they were excluded from the analysis) a wine cellar/vineyard. Therefore, the frequency of visiting vineyards it is showed in table number 1 : 
Table no. 1: Frequency of visiting wine destinations

\begin{tabular}{|l|l|l|l|}
\hline & Frequency & Percent & Valid Percent \\
\hline Once a year & 133 & 52.8 & 52.8 \\
\hline More than once a year & 88 & 34.9 & 34.9 \\
\hline Once a month & 13 & 5.2 & 5.2 \\
\hline More than once a month & 5 & 2.0 & 2.0 \\
\hline Never & 13 & 5.2 & 5.2 \\
\hline Total & 252 & 100.0 & 100.0 \\
\hline
\end{tabular}

Source: Customers' expectations regarding wine tourism in Romania (Gurgu, A., 2019)

As showed, most of the respondents are visiting wine destinations once a year - $52.8 \%$ of them, while $34.9 \%$ are going more than once a year. The reason for which people are visiting only once a year a wine cellar or a vineyard is because this is not a usual type of trip and only people who are truly passionate or a connoisseur of wine practice this type of tourism. However, only $5.2 \%$ and $2 \%$ of the total of respondents are visiting these places once a month or more, they are representing the people who are working in this sector or are engaged with wines for various reasons. According to the statistical analysis, the distribution reflects that majority, 133 people, are visiting a vineyard once a year while only 5 people out of 252 are regular visitors.

To provide insights about which wine destination from Romania is the most visited, the respondents were asked which area they visited. As it can be seen in the figure from below, number 1 - the most visited wine destination is Moldova - Cotnari with 23\%, followed by Muntenia - Dealu Mare with 22\% and Dobrogea - Murfatlar with $19 \%$. The least visited area is Oltenia - Dragasani, which cumulated only $10 \%$ from the respondents.

The explanation for which the first two areas are the most visited is that the most known wines come from these places, Moldova is also known for its wine history while Dealu Mare is close to Bucharest.

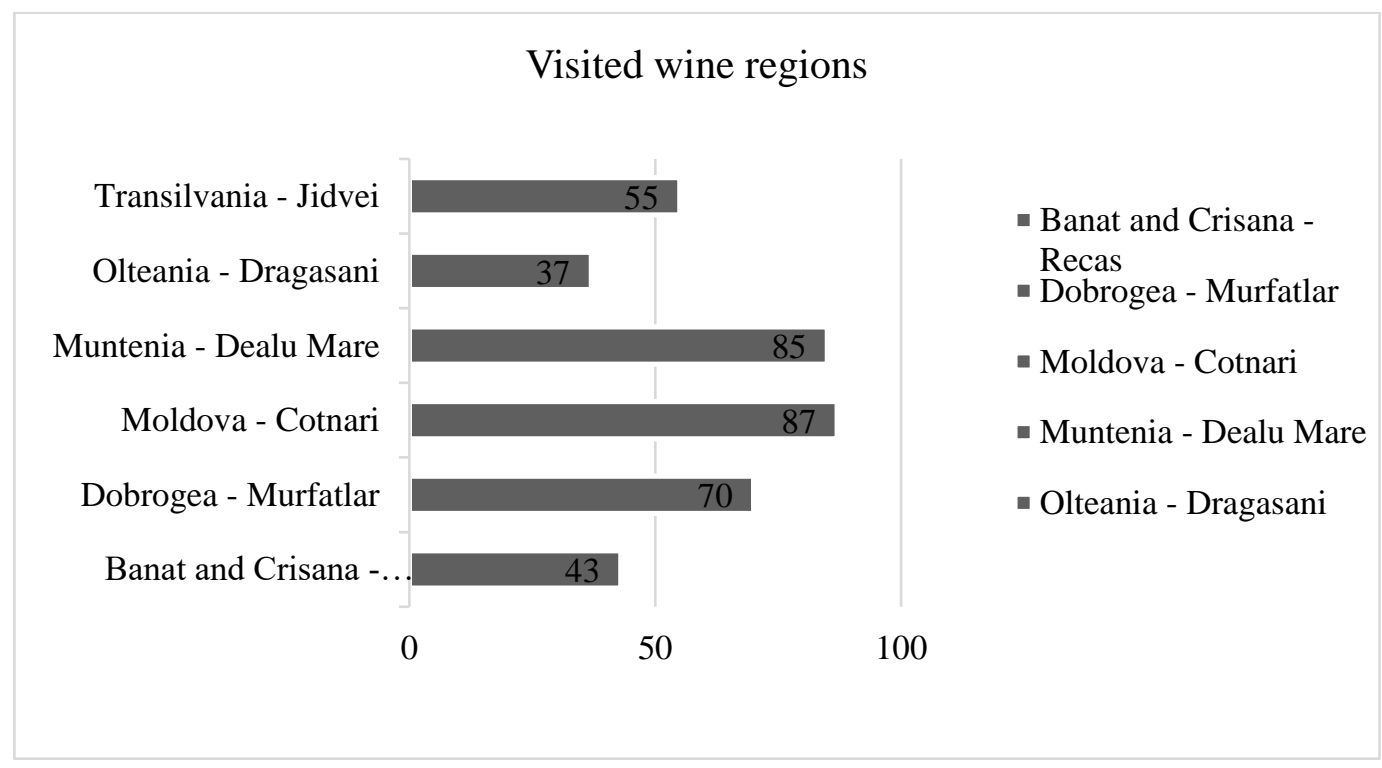

Fig. no. 1: Visited wine destinations from Romania

Source: Customers' expectations regarding wine tourism in Romania (Gurgu, A., 2019)

The trend of visiting wine cellars in Romania was analysed and it reflects that $86 \%$ of the respondents would like to visit more wine destinations in the country and to discover new places, while only $14 \%$ prefer to go back to the vineyards already visited.

On the other hand, the factors that influence people to visit this type of places were reputation of the wine or vineyards, events, word of mouth, internet and mass media. 


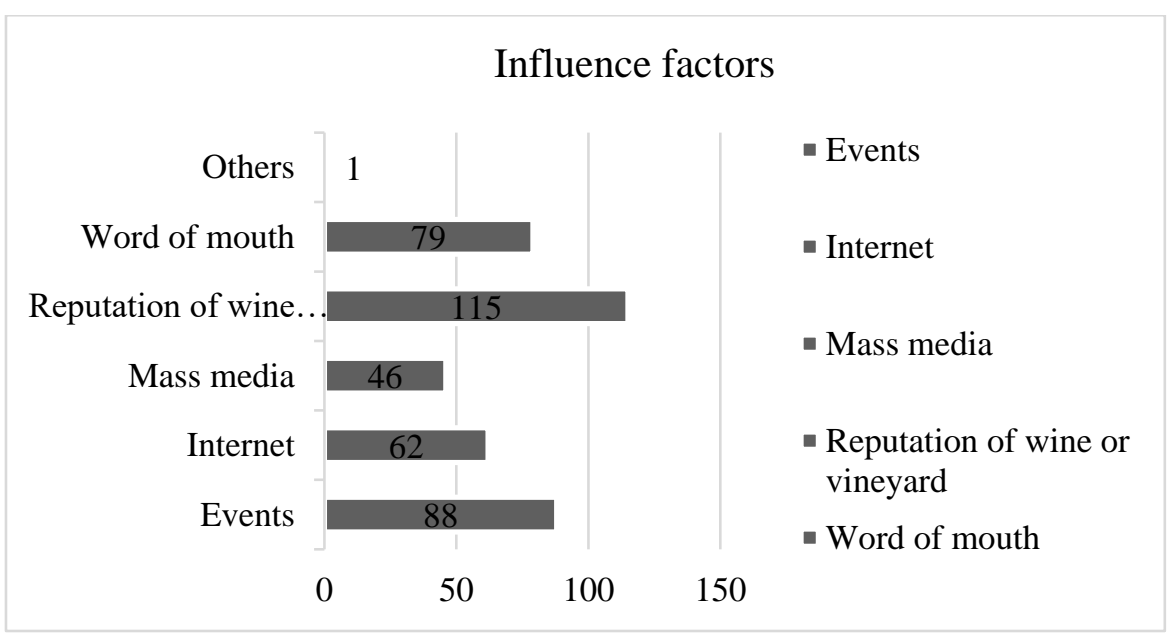

Fig. no. 2: The influence factors of wine tourists

Source: Customers' expectations regarding wine tourism in Romania (Gurgu, A., 2019)

In the figure above it can be observed that reputation is the main influence factor when choosing to visit such a place, with $29 \%$. This can be explained due to the fact that wine tourism is not so developed in Romania like in other countries, hence people have to know the wine brand in order to be curious to discover the place from where the wine comes. Events, like wine festivals or gastronomic events, also influence the decision for visiting wine destinations, $23 \%$ of the respondents decide to go after they have contact with wine cellars owners during these type of activities. Also, word of mouth - $20 \%$ encourage people to visit as some people already experienced wine tourism. Internet and mass media cumulate only $16 \%$ due to the fact that wine tourism is not so promoted at the moment.

After analysing the data, it seems that Romania has a positive trend to develop wine tourism as more and more people become aware of this new experience. Furthermore, the wine sector should be improved because people manifest interest in visiting wine destinations. Some of the advantages that can encourage wine tourism are the increasing wine sales, customers improve their knowledge about wines and because it creates brand awareness.

\subsection{Quantitative analysis}

For the quantitative analysis the respondents were numbered as per below table number 2. From a total of 12 responses only 9 were validated due to the reason that the other 3 mentioned that they do not offer wine tourism services at that moment.

Table no. 2: The respondents

\begin{tabular}{|l|l|}
\hline Respondent & Wine Region \\
\hline R1 & Moldova - Cotnari \\
\hline R2 & Dobrogea - Murfatlar \\
\hline R3 & Transilvania - Jidvei \\
\hline R4 & Banat and Crisana - Recas \\
\hline R5 & Muntenia - Dealu Mare \\
\hline R6 & Moldova - Cotnari \\
\hline R7 & Oltenia - Dragasani \\
\hline R8 & Muntenia - Dealu Mare \\
\hline R9 & Muntenia - Dealu Mare \\
\hline
\end{tabular}

Source: Customers' expectations regarding wine tourism in Romania (Gurgu, A., 2019)

Starting with the first question of the interview "Taking into consideration that in the past few years wine tourism in Romania is more acquainted: Do you consider that wine tourism is contributing to wine industry or support the wine production? Please argue your response.", the general opinion of the respondents was that wine tourism is directly influencing wine production due to the main reason that people are going to wine cellar to learn about wines, to discover how they are produced, and moreover 
they can buy wine directly from the source, that consist in extra incomes. This way the producers can expand their direct selling method, as R1 states:

\begin{abstract}
"It has a very important contribution, first of all it helps to cultivate the market, we receive over 1000 tourists every year, most of them young people from corporations who leave with a lot of information and bottles of wine which they will share with friends, family, etc. Secondly, tourism contributes to the health of the cash flow both by the number of bottles sold and the margin (instead of giving a distribution discount, we apply a commercial surcharge to align the sale price with that in specialty stores)."
\end{abstract}

The second question asks about producer's opinion about Romanian wine tourism, the key words extracted are: upward trend, incipient phase, in the process of development. The wine producers are arguing that wine tourism in Romania is in a continuum development. However, there are some facts that influence the slow development of wine tourism, for example lack of infrastructure, poor marketing, it is not really supported by the government, travel agencies that offer wine tours packages are almost non-existent on the market etc.

From the perspective of type of services, when asked "Which are the services and activities that you offer to consumers at your winery/vineyard? " the wine producers offer is limited only to wine tastings, walks in the vineyard and visits of the wine cellar. As the services are limited and lie in only two or three main activities, the wine producers would like to expand in order to be able to offer completed wine experiences to their customers, for instance, accommodation, meals and other entertainment activities.

The main advantage for wine producers after tourists visits their wine cellar is that, afterwards people are looking for their wines in retail, even though some wines are made exclusively for Horeca industry. The fact that wine producers are trying to improve and expand their services in order to meet customer expectations, comes with a positive impact for the development of both industries, wine and tourism.

To summarize the analysis, the research acknowledges that wine tourism in Romania is in the process of development as it is a new product on tourism market. In order for people to become more familiar with it, wine producers should invest more in marketing to attract customers. Also, wine producers should improve and expand their services based on the support from interested parts and also innovate their wine making process to enhance quality of wine.

\title{
Conclusions
}

The research has revealed that wine tourism in Romania has been in process of continuous development. The concept has attracted more people due to the fact that it has emerged as a new product on tourism market. Moreover, due to COVID-19 pandemic people have increased their desire to travel more inside their countries.

On the other hand, an important motivation factor to develop wine tourism is that people are looking for new experiences and new places to visit. Generally, is known the fact that wine is a perfect way to relax, it brings people together and is associated with communication and entertainment. On top of that, people are interested to expand their knowledge about wine and the best way to do that is directly at the wine cellar. In this way they can be taught how to taste wine in a professional manner and how to pair food with wine.

In order for wine producers to improve their services, they stated in interviews that they need financial support from government. However, as the Ministry of Agriculture and Rural Development presented Programul Național de Sprijin in sectorul vitivinicol 2019-2023 (National Support Program in the wine sector 2019-2023) during Viticon conference, the wine producers were encouraged to apply to get the support. In addition to this, the private sector is also offering support to viticulture sector through financial services, conventional and organic agriculture and other products that keep vineyard healthy and protected from bacteria.

Also, taking into consideration the influence factors that make people visit the wine destinations, wine producers should invest more in their marketing, as one of the advantages of wine tourism is increasing brand awareness. In addition to this, alliances and partnerships between wine producers from the same region should be created in order to expand their activity. For example, the wine cellars from the same area can be visited in a one-day trip where people can participate to vineyard tours and wine tastings. 
Also, wine producers should collaborate with travel agencies to create, promote and sell their touristic services.

Finally, for a positive increase of revenue from various services related to wine, not only from wine selling the Romanian producers are encouraged to adopt wine tourism services. Through the support offered to wine sector by multiple interested parts the improvement on the sector should bring a positive influence on the business that would further reflect in development of wine tourism in Romania.

\section{References}

Afonso, C., Silva, G.M., Goncalves, H.M. and Duarte, M., 2017. The role of motivations and involvement in wine tourists' intention to return: SEM and fsQCA findings. Journal of business research, 89, pp. 313-321.

Bolcu, C., 2021. Turismul viticol in Romania - oportunitati neexploatate. Imperial Transilvania. [online] Available at: https://www.imperialtransilvania.com/ro/2021/01/28/citeste-stirea/argomenti/events1/articolo/turismul-viticol-in-romania-oportunitati-neexploatate.html [Accessed on 24th of March 2021].

Charters, S. and Ali-Knight, J., 2002. Who is the wine tourist? Tourism Management 23, pp. 311-319.

Crame Romania, (n.d.). Romania - Wine Map - Wineries. Publisher details unavailable. [online] Available at: https://www.crameromania.ro/en/regions [Accessed on 27th of March].

Dobreanu, I., 2021. GRAMMA Wines intra pe piata de turism viticol cu mici case in mijlocul viei. Economica.net. [online] Available at: https://www.economica.net/gramma-wines-intra-pe-piata-de-turism-viticol-cu-micicase-in-mijlocul-viei_497536.html [Accessed on 20th of May 2021].

Getz, D., and Brown, G., 2004. Critical success factors for wine tourism: a demand analysis. Tourism Management, 27. pp. 146-158.

Gurgu, A., 2019. Customers' expectations regarding wine tourism in Romania. Master of Science. Manchester Metropolitan University.

Hall, C.M. and Mitchell, R., 2008. Wine Marketing: A practical guide. Butterworth-Heinemann, Elsevier.

Hall, C.M., (1996). Wine Tourism in New Zealand. Tourism and Services Management. Victoria University of Wellington.

Hall, C.M., Sharples, L., Cambourne, B. and Macionis, N., 2000. Wine Tourism around the World: Development, management and markets. Butterworth-Heinemann, Elsevier.

KeysFin, 2020. Paradoxul vinurilor romanesti: cifra de afaceri mai mica in 2019, dar cel mai bun rezultat net din ultimii 10 ani. Publisher details unavailable. [online] Available at: https://www.keysfin.com /\#!/Pages/News/NewsDetails\&title=paradoxul-vinurilor-romanesti-cifra-de-afaceri-mai-mica-in-2019dar-cel-mai-bun-rezultat-net-din-ultimii-10-ani [Accessed on 28th of April 2021].

Nedelcu, A., 2014. Potential of wine tourism in Romania. Case study: Dealu Mare Vineyard. Publisher details unavailable. pp. 50-55. [online] Available at: https://ideas.repec.org/a/cbu/jrnlec/y2014vspecialp5055.html. [Accessed on 20th of March 2021].

Quinlan, C., 2011. Business Research Methods. Hampshire, Cengage learning (EMEA) Ltd.

Rapoarte privind ecosistemele regionale de inovare, (2017). Potentialul de specializare inteligenta in domeniul agro-alimentar in Regiunea Sud-Est. [online] Available at: https://uefiscdi.gov.ro/resource-89258 [Accessed on 20th of March 2021].

Sorensen, Z., 2013. Exploring wine tourism in Bulgaria. A pathway to sustainable rural and tourism development? Master of Arts. The International Institute for Industrial Environmental Economics.

Stiriagrigole.ro, 2020. Turismul viticol din Romania, in scadere tot mai mare. Care este cauza? Publisher details unavailable. [online] Available at: https://www.stiriagricole.ro/turismul-viticol-din-romania-in-scaderetot-mai-mare-care-este-cauza-59947.html [ Accessed on 28th of April 2021].

Tanase, M., 2017. Producatorii de vin se implica in dezvoltarea enoturismului. Trendshrb.ro. [online] Available at: https://www.trendshrb.ro/actual/producatorii-de-vin-se-implica-dezvoltarea-enoturismului/ [Accessed on 23rd of March 2021].

Thanh, T.V. and Kirova, V., 2017. Wine Tourism experience: A netnography study. Journal of Business Research, 83. pp. 30-37.

Viticon Conference, 2021. Viticon 2021. [video online] Available at: https://agricover.ro/evenimente/ viticon2021/ [Accessed on 18th of March].

World Tourism Organization (UNWTO), 2016. Wine Tourism - a growing tourism segment. [online] Available at: https://www.unwto.org/archive/global/press-release/2016-09-09/wine-tourism-growing-tourismsegment [Accessed on 4th of May 2021] 